\title{
A NEW SPECIES OF THYSANOTE KROYER, 1863 (COPEPODA: SIPHONOSTOMATOIDA: LERNAEOPODIDAE), A FISH PARASITE FROM THAILAND
}

\author{
Wojciech PIASECKI ${ }^{1 *}$, Susumu OHTSUKA ${ }^{2}$, and Reiko YOSHIZAKI ${ }^{2}$ \\ ${ }^{1}$ Division of Fish Diseases, Agricultural University of Szczecin, Szczecin, Poland \\ ${ }^{2}$ Takehara Marine Science Station, Setouchi Field Science Center, Graduate School of Biosphere Science, \\ Hiroshima University, 5-8-1 Minato-machi, Takehara, Hiroshima 725-0024, Japan
}

Piasecki W., Ohtsuka S., Yoshizaki R. 2008. A new species of Thysanote Krøyer, 1863 (Copepoda: Siphonostomatoida: Lernaeopodidae), a fish parasite from Thailand. Acta Ichthyol. Piscat. 38 (1): 29-35.

Background. Thysanote Krøyer, 1863 (Copepoda, Siphonostomatoida, Lernaeopodidae) comprises 19 species of marine parasite that infect fishes. This report establishes a new Thysanote species based on new collections of copepods. The taxonomic status of this genus is not fully understood and therefore more relevant contributions are needed.

Materials and Methods. The species description is based on male and female specimens collected from the olfactory sacs of spotted scat, Scatophagus argus, captured off Thailand in 2003. The specimens were studied using standard light and scanning electron microscopy techniques.

Results. The studied specimens were assigned to Thysanote based on the presence of maxillary- and posterior processes and they exhibited unique characteristics such as distinctly short length of their maxillary- and posterior processes.

Conclusion. Based on their unique characteristics, a new Thysanote species is erected, and named Thysanote chalermwati n. sp., thus bringing the number of congeners to 20 .

Keywords: new species, Thysanote, fish parasite, nasal cavity, spotted scat, Scatophagus argus

\section{INTRODUCTION}

One of the largest families of fish parasites of the subclass Copepoda (Arthropoda: Crustacea) is the family Lernaeopodidae. They affect predominantly marine fishes and are very host specific. The genus Thysanote Krøyer, 1863 is an example of marine lernaeopodids. It comprised, until recently, 19 valid species. They parasitize teleost fishes representing different families, living in different geographical areas and different habitats. The primary synapomorphy supporting the genus is the presence of maxillary processes and posterior processes of the female. The most recent and the most comprehensive discussion of the genus, including the taxonomic key, was published by Kabata and Tareen (1981). Since then, the genus was expanded by the inclusion of two more species, namely: T. polyfimbriata Prabha et Pillai, 1981 and T. nudibranchiata Pillai, Prabha et Balaraman, 1982. This report describes a new species of the genus, collected from the spotted scat off Thailand.
Material: A total of 15 females of the copepod (with males attached) was collected from the nasal cavities of spotted scat, caught 25-27 December 2003 off Ang Sila, Chon Buri (Gulf of Thailand). The parasites were preserved in $70 \%$ ethyl alcohol. Observations of five females ( 2 ovigerous) and two males cleared in lactic acid were subsequently made using a light microscope (Nomarski interference-contrast), a modification of modified "wooden slide method" of Humes and Gooding (1964). Figures were drawn using a drawing tube. Additional specimens of males and females were studied using scanning electron microscope. Terminology generally follows that proposed by Kabata (1979). Female specimen drawn en toto (Ang Sila, 27 December 2003, from spotted scat No. 12) is the holotype, male depicted en toto (Ang Sila, 27 December 2003, from spotted scat No. 8) is the allotype. Other 3 females and 2 males become paratypes. The types have been deposited in the Crustacea Collection of the Museum für Naturkunde, Berlin, Germany: ZMB 27677 (the museum provides a single number for all types of a given species).

\footnotetext{
* Correspondence: Dr hab. Wojciech Piasecki, prof. nadzw., Zakład Chorób Ryb, Wydział Nauk o Żywności i Rybactwa, Akademia Rolnicza w Szczecinie, ul. Kazimierza Królewicza 4, 71-550 Szczecin, Poland, phone: +4891-423-1061 ext. 226, fax: +4891-423-1347, e-mail: piasecki@fish.ar.szczecin.pl
} 


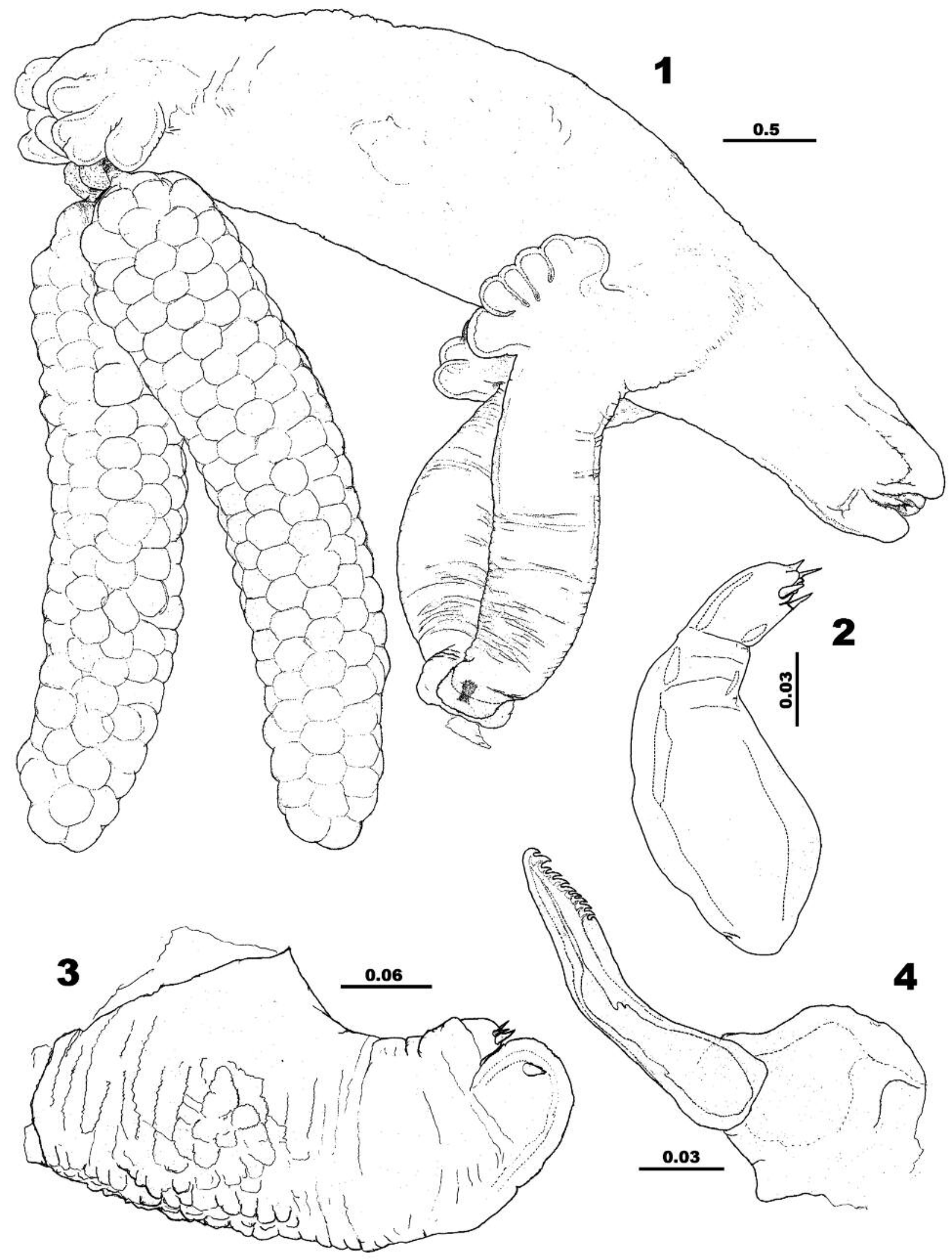

Figs. 1-4. Thysanote chalermwati n. sp.; female; Fig. 1. General habitus; ovigerous; lateral (holotype); Fig. 2. First antenna; Fig. 3. Second antenna; Fig. 4. Mandible; Scale bars in millimetres 

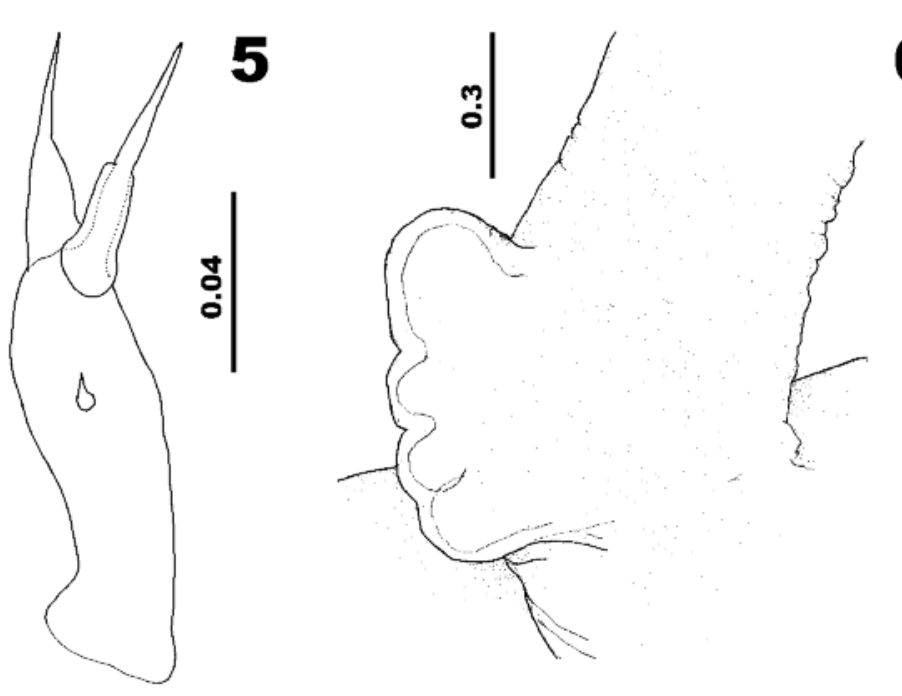

6
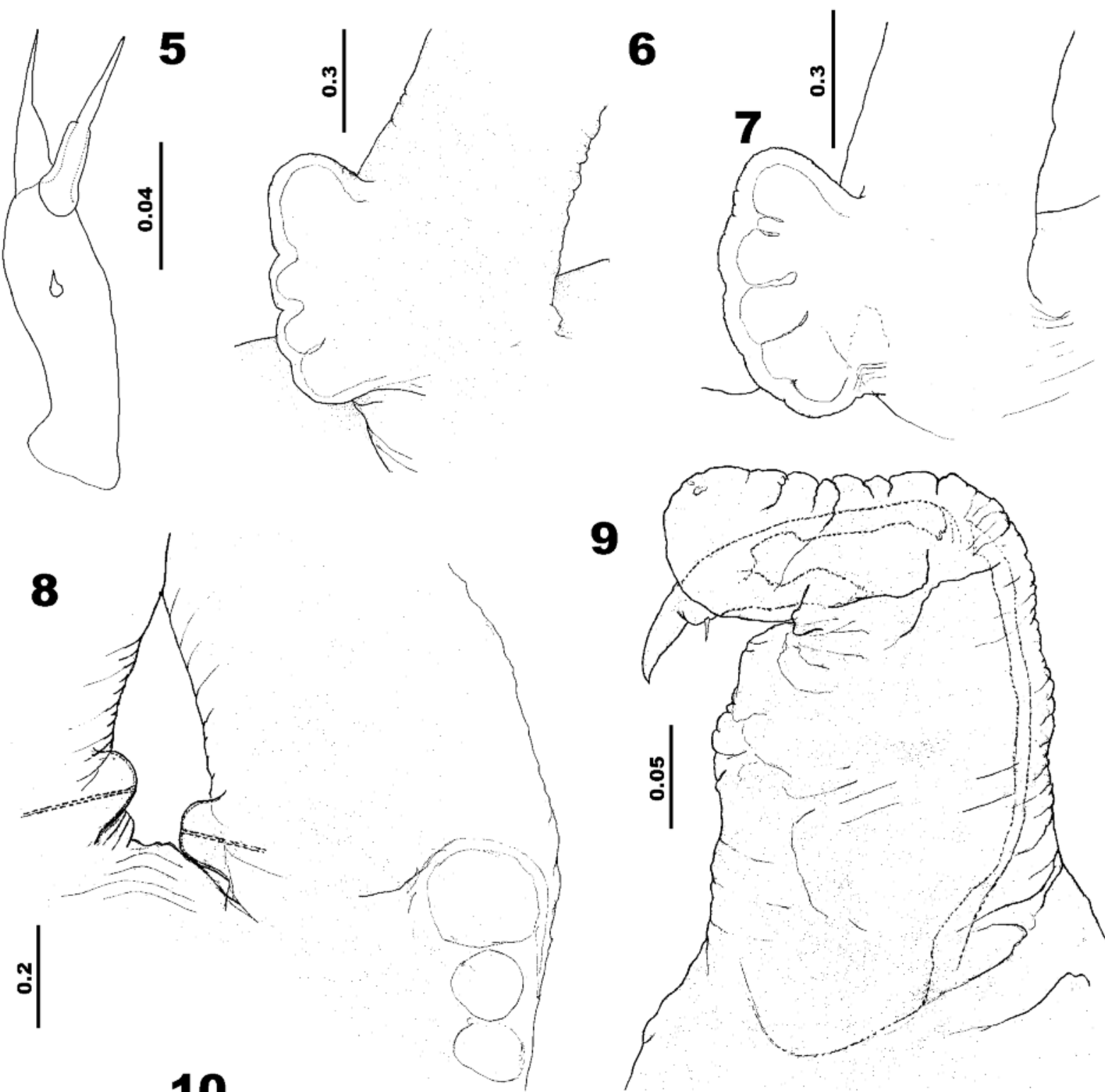

9
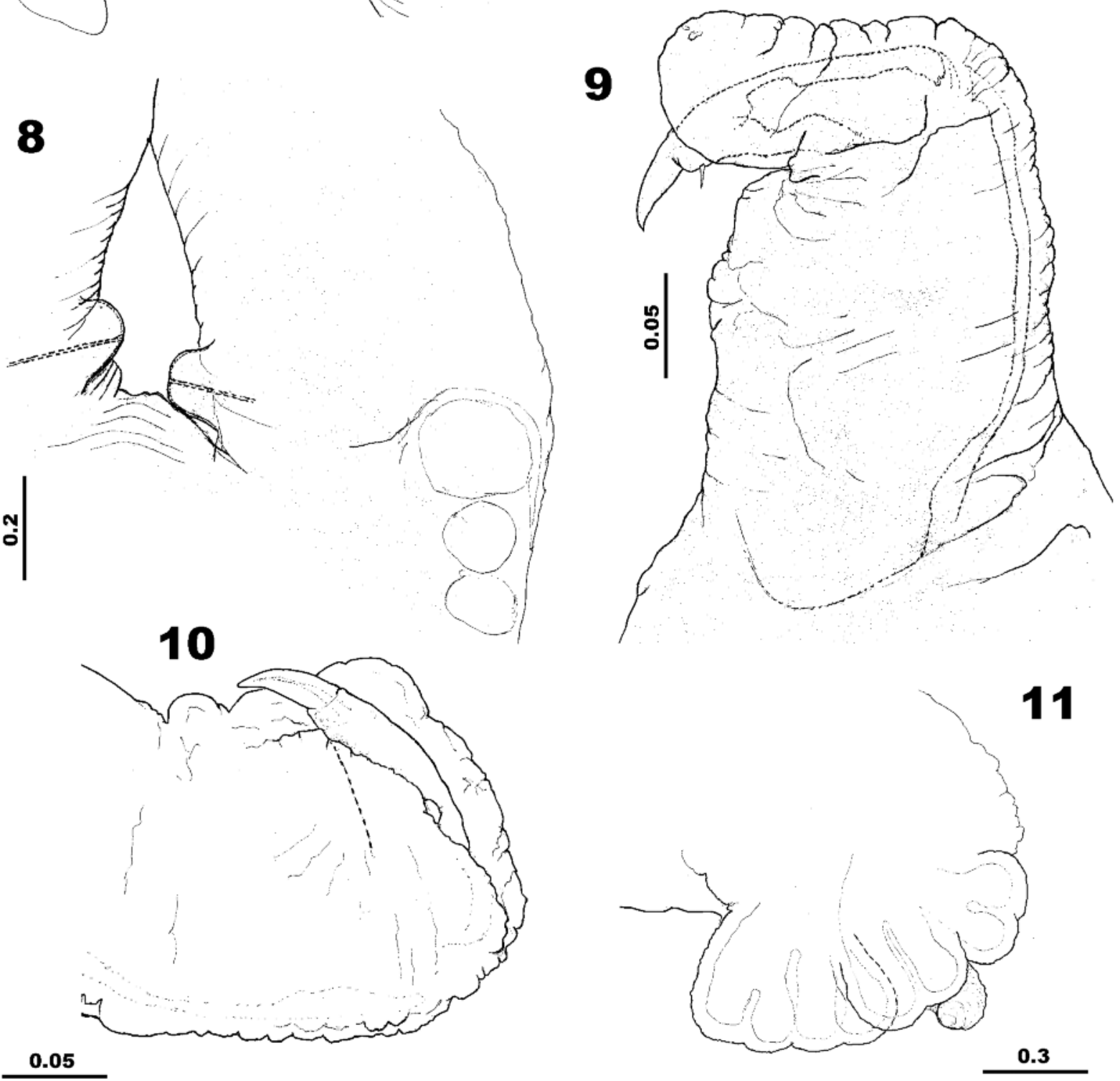

Figs. 5-11. Thysanote chalermwati n. sp.; female; Fig. 5. First maxilla. Fig. 6. Maxillary processes; Fig. 7. Maxillary processes of another specimen; Fig. 8. Orifices of maxillary glands, posterior; Fig. 9. Maxilliped (left), ventral; Fig. 10. Maxilliped (right), dorsal. Fig. 11. Posterior processes, lateral; Scale bars in millimetres 
Host: spotted scat, Scatophagus argus (Linnaeus, 1766) (Actinopterygii: Perciformes: Scatophagidae).

Etymology: the species name, Thysanote chalermwati, is intended to honour Dr Kashane Chalermwat who hosted one of the authors (S.O.) during his stay in Thailand.

\section{FEMALE}

Body elongate $(5.67 \mathrm{~mm}$ long) (Fig. 1) consisting of cephalothorax and genital trunk. Cephalothorax $(1.41 \mathrm{~mm}$ long) cylindrical, in line with genital trunk, constituting one-third of body and slightly shorter than "maxillary arms" (second maxillae). Cephalothorax diameter at base similar to that of genital trunk. Cephalothorax tapering slightly towards anterior end. Genital trunk $(3.26 \mathrm{~mm}$ long), constituting two-thirds of body, cylindrical, longer than "maxillary arms". External layer of cuticle thick, probably elastic, with dense wrinkles, resembling elephant skin.

First antenna (Figs. 2, 14) uniramous, short $(177 \mu \mathrm{m}$ long), indistinctly three-segmented. Basal segment ellipsoid, larger than two other segments combined. Second segment shortest, length not exceeding width. Terminal segment with round tip. Armament confined to tip of terminal segment, typical lernaeopodid, with at least 5 elements.
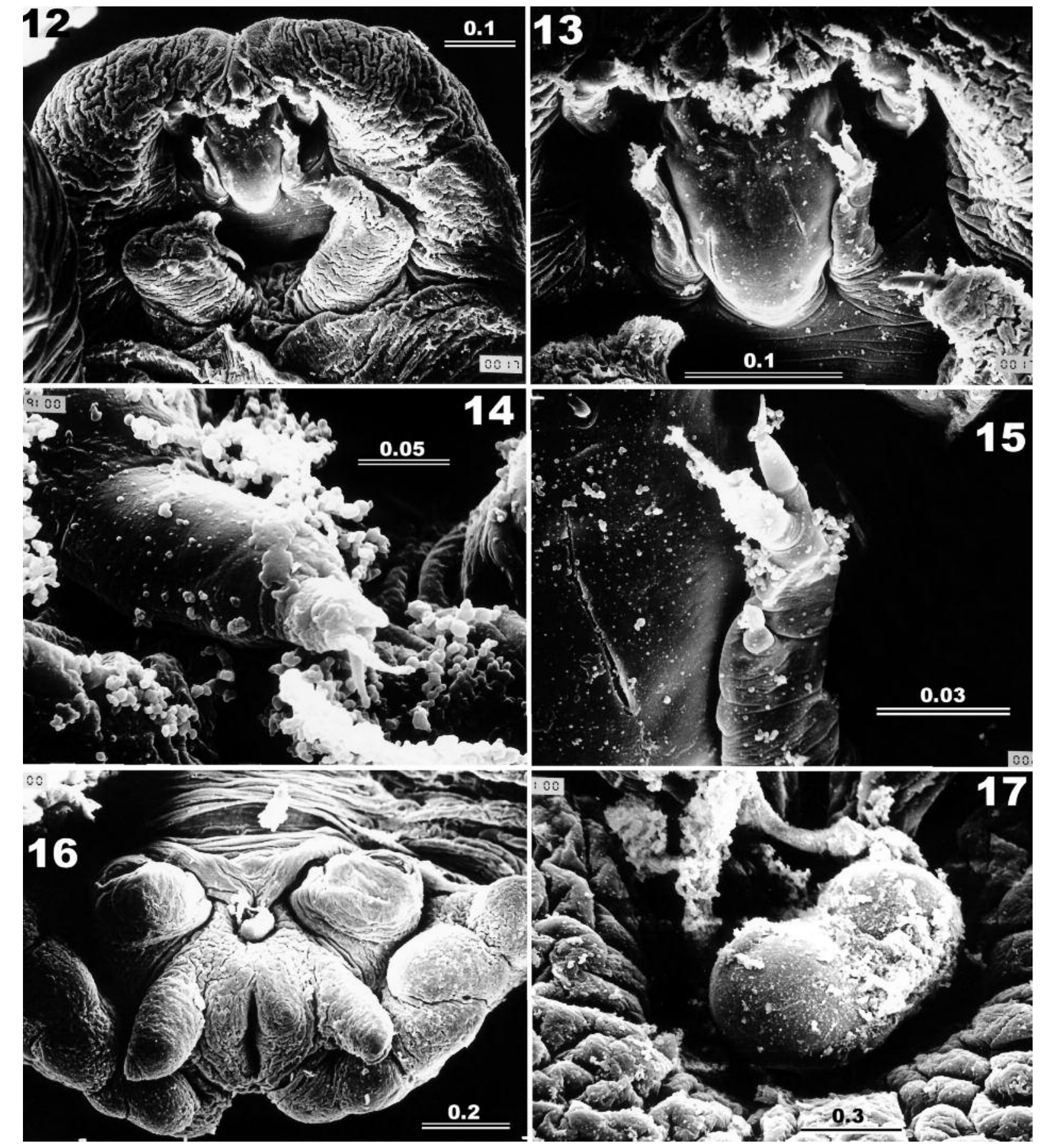

Figs. 12-17. Thysanote. chalermwati n. sp.; female, SEM micrographs; Fig. 12. Anterior part of cephalothorax, ventral; Fig. 13. Mouth cone and first maxillae; Fig. 14. First antenna; Fig. 15. First maxilla; Fig. 16. Posterior part of genital trunk, ventral; Fig. 17. Spermatophore; Scale bars in millimetres 
Second antenna (Fig. 3) biramous, robust, (380 $\mu \mathrm{m}$ long) bent over mouth cone in fixed specimens. Segmentation obliterated by thick, wrinkled cuticle ("elephant skin"). Rami short. Exopod unsegmented, armed with stout denticle. Endopod one-third shorter, two-segmented. Segments of equal length with width exceeding length.

Mandible (Fig. 4) two-segmented typical for Lernaeopodidae species, heavily sclerotized. Basal segment strong and globular. Terminal segment (121 $\mu \mathrm{m}$ long). Denticulate edge with 10 teeth, dental formula: P2, S1, B7.

First maxilla (Figs. 5, 13, 15) biramous, small $(138 \mu \mathrm{m}$ long), delicate. Exopod tiny, ventrally oriented, consisting of short conical outgrowth. Endopod with two large apical setiferous processes.

Second maxilla (Figs. 1, 6-8) large (2.31 mm long), cylindrical, elongate, transformed into powerful "arms", distally joined to opposite appendage by bulla. Constricted subterminally into terminal peribullar collar. Bulla small, inconspicuous, mushroom-shaped (Fig. 1). Maxillary processes, (Fig. 1) located postero-ventrally near basal portion of appendage, very short, toe-like; round in cross- section, length smaller or slightly exceeding bulla's diameter. Smaller females with fewer and shorter processes (Figs. 6, 7); larger females with five processes, outer ones showing signs of bifurcation (Fig. 1). Orifices of maxillary glands mounted on hemispherical processes, located medially at base of appendage (Fig. 8).

Maxilliped (Figs. 1, 9, 10, 12), uniramous, subchelate, located ahead of second maxillae subterminally on cephalothorax (Figs. 1, 12). Segmentation obscured by thick layer of wrinkled cuticle ("elephant skin"). Subchela consisting of shaft and claw. Shaft with small seta at base of claw, claw smooth, without secondary teeth. Almost entire subchela covered on ventral side by pillow-like cuticular fold.

Thoracic appendages: not located, probably absent.

Posterior processes (Figs. 1, 11) located on posterolateral margins of trunk; better developed than maxillary processes. Two short and branching (palm-like) processes on each side of body, each consisting of three toe-like processes. Dorsal-most process and ventral-most one showing signs of secondary branching.
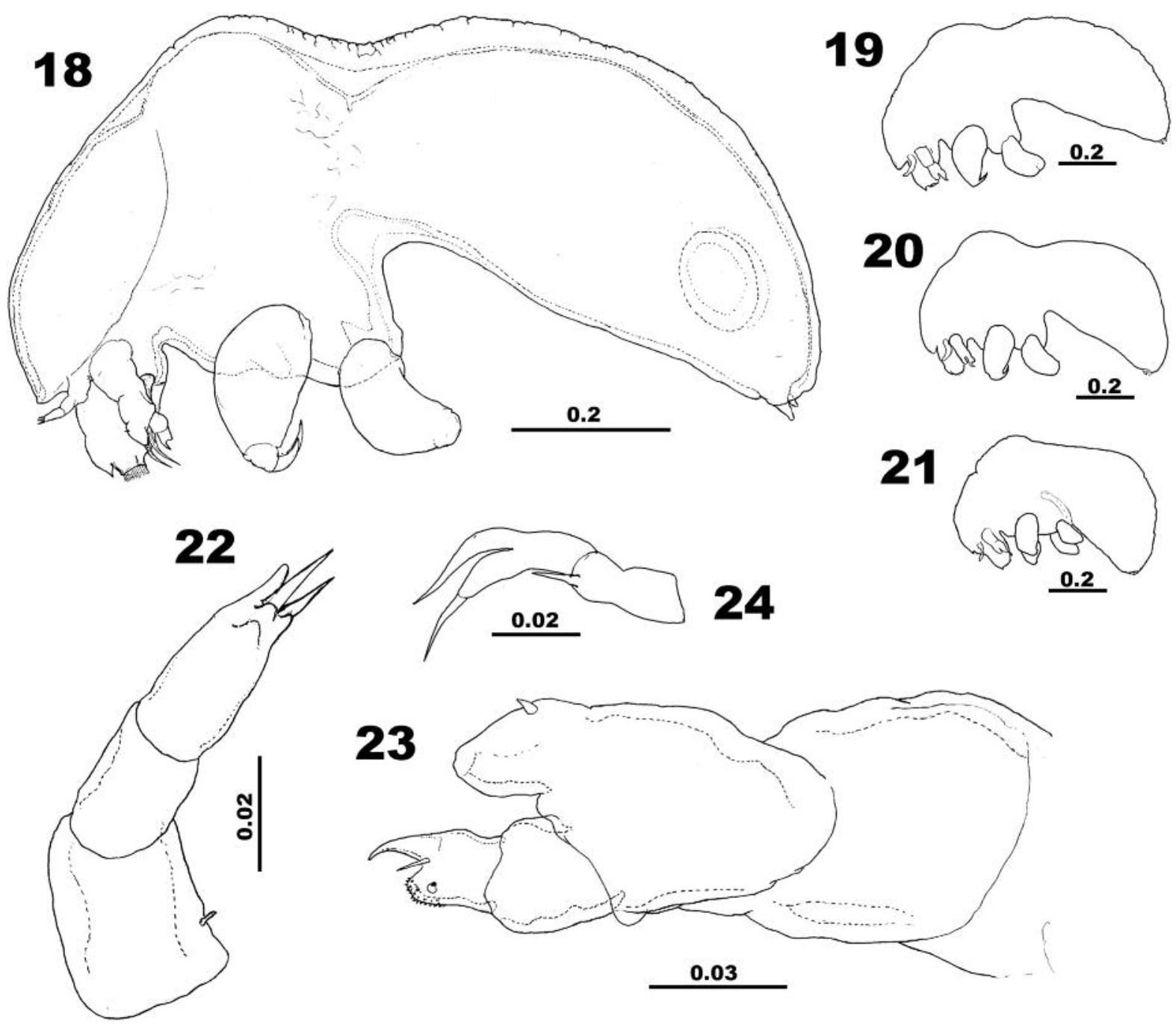

Figs. 18-24. Thysanote chalermwati n. sp.; male; Fig. 18. Whole; lateral (allotype); Figs. 19-21. Silhouettes of other male specimens; lateral; Fig. 22. First antenna; Fig. 23. Second antenna; Fig. 24. First maxilla; Scale bars in millimetres 
Egg sacs (Fig. 1) multiseriate (3.88-mm long), egg diameter ca. $185 \mu \mathrm{m}$.

Perianal area (Fig. 16) slightly raised, located in centre of posterior margin (Fig. 11), flanked by reduced caudal rami.

Caudal ramus (Fig. 16) consisting of single, moderately elongate, unarmed, digitiform process.

Genital orifices (egg-sac outlets) slit-like, on top of paired, regular hemispheric elevations (Fig. 16). Small, paired, ill-visible copulatory poles (sometimes marked by attached spermatophore, Fig. 17) between genital orifices. MALE

Similar to male of Parabrachiella. Body moderately elongate (1.22 mm long) (Figs. 18-21) consisting of two parts of comparable length: cephalothorax, with 6 pairs of appendages, and slender genital trunk. Distinct dorsal shield (Fig. 18), cephalothorax (0.57 mm long) at angle to genital trunk, separated from latter by constriction. Genital trunk $(0.7 \mathrm{~mm}$ long) slightly longer than cephalothorax. Dorsal- and lateral parts of body behind dorsal shield covered by wrinkled thick cuticle.

First antenna (Figs. 18, 22, 25, 26) three-segmented, similar to that of female although slimmer. Terminal segment only slightly longer than others, tip armed with 3 setae and 3 tubercles. Basal segment with minute seta (whip).
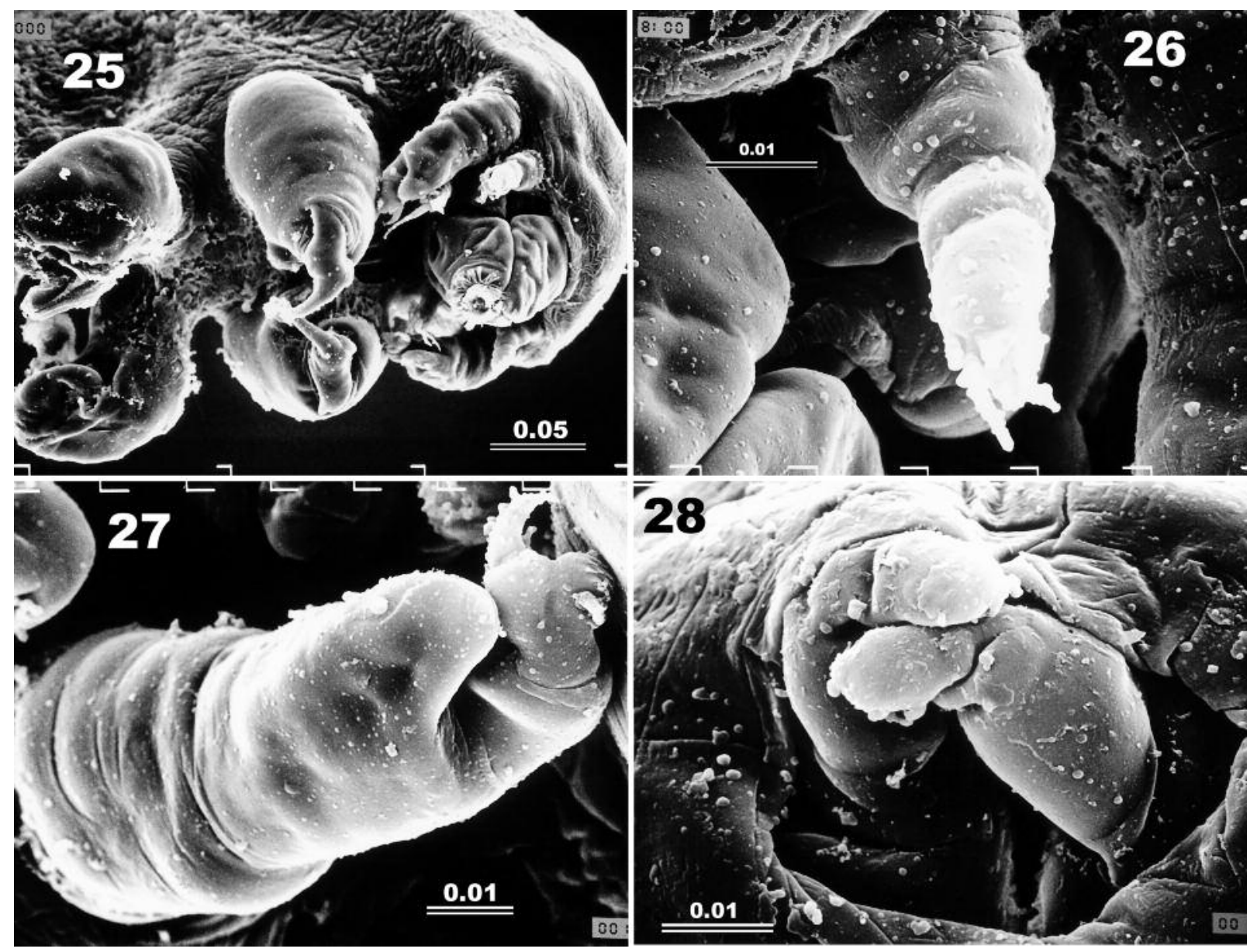

Figs. 25-28. Thysanote chalermwati n. sp.; male, SEM micrographs; Fig. 25. Cephalothorax ventro-lateral; Fig. 26. First antenna; Fig. 27. Second antenna; Fig. 28. Caudal rami; Scale bars in millimetres
Second antenna (Figs. 18, 23, 25, 27) biramous; sympod two segmented. Unsegmented exopod with lateral spine; distinctly shorter than endopod. Endopod two segmented, terminally armed with curved hook 1 , associated small seta 2, and denticulated pad 4.

Mandible, not studied.

First maxilla (Fig. 24) similar to that of female; ventral exopod more pronounced and with longer seta.

Second maxilla (Figs. 18, 25) typical lernaeopodid. Corpus short, cylindrical, robust. Subchela distinctly narrower, slim, with long, sharp, curved claw.

Maxilliped (Figs. 18, 25) typical lernaeopodid. Corpus short, cylindrical, robust. Subchela short with small, robust claw.

Thoracic appendages: not located, probably absent.

Caudal rami (Figs. 18, 28) digitiform, partly hidden in pocket-like depression at terminus of genital trunk.

\section{DISCUSSION}

The genus Thysanote consists of 20 valid species (including the presently described new species): T. appendiculata (Steenstrup et Lütken, 1861); T. pomacanthi Krøyer, 1863; T. fimbriata (Heller, 1865); T. lobiventris (Heller, 1865); T. multifimbriata (Bassett-Smith, 1898); T. longimana Wilson, 1913; T. epinepheli Yamaguti, 1939; T. exornata Brian, 1939; T. triloba Pearse, 1952; 
T. goodi Causey, 1960; T. rastrelligeri Rangnekar, 1961; T. eleutheronema Rangnekar, 1961; T. decemfimbriata Pillai, 1962; T. furcata Kirtisinghe, 1964; T. heterodactyla Kirtisinghe, 1964; T. gymnobrachiata Kabata, 1968; T. alternans Kabata et Tareen, 1981; T. polyfimbriata Prabha et Pillai, 1981; T. nudibranchiata Pillai, Prabha et Balaraman, 1982; T. chalermwati $\mathrm{n}$. sp.

Two nominal species $T$. decemfrimbriata Pillai, 1962 and T. octofimbriata Tripathi, 1962 were transferred to synonymy with T. eleutheronema Rangnekar, 1961 by Pillai (1967) (and sustained by Pillai 1985), but Kabata and Tareen (1981) argued that T. decemfimbriata should be considered a valid species. It should be emphasized, however, that both nominal species were found on the same fish species, caught from the same locality. We also included with hesitation in our list three species without maxillary processes: T. gymnobrachiata, T. nudibranchiata, and T. multifimbriata. Their descriptions do not include appendages, and it is possible that they all belong in another genus (Parabrachiella?) and as such should be removed from the above list.

The most recent comprehensive discussion and the identification key for species of the genus Thysanote was provided by Kabata and Tareen (1981). It did not include the two most recent contributions, namely $T$. polyfimbriata and T. nudibranchiata (cf. Prabha and Pillai 1981, Pillai et al. 1977). Their inclusion into the Kabata and Tareen (1981) key should be easy: T. nudibranchiata does not have maxillary processes and T. polyfimbriata has a multitude of maxillary- and posterior processes with branched, pointed tips, giving them a "bushy" appearance.

T. chalermwati $n$. sp., the new species described above, distinctly differs from its congeners, mainly in having very small (vestigial) maxillary- and posterior processes.

The description of this new species was presented in 2005 at the 9th International Conference on Copepoda, held in Hammamet, Tunisia, but without publishing its name or other details (Piasecki et al. 2005). It is worth to mention, however, that Thysanote sp., recently found by Yuniar et al. (2007) in Indonesia, from the same fish, is probably conspecific with the one presently described by us. The paper of Yuniar et al. (2007) contains only overall photograph with no morphological description and therefore the parasite is identified at the generic level only.

\section{ACKNOWLEDGEMENTS}

We would like to express our sincere thanks for Dr K. Chalermwati and Mrs Khwanruan Srinui (Burapha University) for collection of the host in Thailand. This project was partly supported by grant-in-aids from the Japan Society for the Promotion of Science for a scientific research awarded to SO (No. 20380110) and for the Multilateral Cooperative Research Program (Coastal Oceanography).

\section{REFERENCES}

Humes A.G., Gooding R.U. 1964. A method for studying the external anatomy of copepods. Crustaceana 6: 238-240.

Kabata Z. 1979. Parasitic Copepoda of British Fishes. The Ray Society, London.

Kabata Z., Tareen I.U. 1981. A new species of Thysanote Krøyer, 1863 (Copepoda, Lernaeopodidae) from the Persian Gulf, with comments on the genus. Systematic Parasitology 3: 97-103.

Piasecki W., Ohtsuka S., Yoshizaki R. 2005. Description of a new species of Thysanote Krøyer, 1863 (Copepoda: Siphonostomatoida: Lernaeopodidae) from Thailand. P. 203. In: 9th International Conference on Copepoda, Hammamet, Tunisia, July 11-15, 2005. Abstract Book.

Pillai N.K. 1967. Copepods parasitic on Indian marine fishesa review. Pp. 1656-1660. In: Proceedings of Symposium on Crustacea-Part V.

Pillai N.K. 1985. Copepod parasites of marine fishes. The Fauna of India. Zoological Society of India, Calcutta.

Pillai N.K., Prabha C., Balaraman K. 1977. (1982) Four species of lernaeopodid copepods new to the fauna of India. Journal of the Marine Biological Association of India 19: $10-15$.

Prabha C., Pillai N.K. 1981. Thysanote polyfimbriata, a new lernaeopodid copepod parasitic on Epinepheles [sic] in Kerala waters. Records of the Zoological Survey of India 79: 179-185.

Yuniar A.T., Palm H.W., Walter T. 2007. Crustacean fish parasites from Segara Anakan Lagoon, Java, Indonesia. Parasitology Research 100: 1193-1204.

Received: 21 March 2008

Accepted: 28 April 2008

Published electronically: 20 June 2008 